\title{
Students' gestures in understanding algebraic concepts
}

\author{
Ida Dwijayanti ${ }^{1}$, I Ketut Budayasa, Tatag Yuli Eko Siswono ${ }^{2}$
}

\begin{abstract}
Abstrak: Penelitian kualitatif ini bertujuan untuk menganalisis gestur siswa dalam memahami konsep aljabar (bentuk aljabar, variable, koefisien, dan konstanta). Penelitian melibatkan 59 siswa di salah satu SMP di Semarang. Data gestur siswa diidentifikasi melalui observasi dan wawancara kemudian dianalisis melalui tahapan kondensasi data, penyajian data, dan penarikan dan verifikasi simpulan. Verifikasi keabsahan data dilakukan menggunakan teknik triangulasi waktu. Hasil penelitian menunjukkan bahwa siswa menggunakan (1) gestur langsung sebagai perwujudan pemahaman konsep koefisien dan variabel dalam bentuk gerakan tangan yang membentuk objek yang dikenali dalam lingkungan sehari-hari, (2) gestur tidak langsung sebagai representasi koefisien dan variabel dalam bentuk gerakan tangan seolah-olah membentuk objek yang dikenali dalam lingkungan sehari-hari kemudian diikuti oleh gerakan tangan yang konsisten dan berulang sebagai representasi koefisien, (3) gestur langsung yang menjadi representasi konstanta melalui gerakan tangan membentuk angka tertentu, dan (4) gestur menulis dan menunjuk untuk memperkuat penjelasan yang diberikan. Penelitian ini menyimpulkan bahwa gestur yang dibentuk siswa dalam memahami konsep bentuk aljabar terdiri dari gestur representasi (gestur representasi langsung dan tidak langsung), gestur menunjuk, dan gestur menulis. Penelitian ini menghasilkan deskripsi penting tentang gestur dan jenis gestur siswa tentang konsep aljabar yang memberikan pemahaman lebih lanjut tentang topik tersebut.
\end{abstract}

\section{Kata kunci: Gestur, Pemahaman konsep, Aljabar}

\begin{abstract}
The purpose of this qualitative exploratory study was to analyze students' gestures in understanding algebraic concepts (algebraic expression, variable, coefficient, and constant). It involved $597^{\text {th }}$-grade students in Semarang city, Indonesia. Students' gestures were identified through interviews and observations, then analyzed in three stages: data condensation, data display, and drawing and verifying conclusion. Time triangulation was utilized to assure data validity. The results showed that students employed: (1) direct gestures as a representation of coefficients and variables in the form of hand movements forming the shape of objects that they recognize in the everyday environment, (2) indirect gestures as a representation of coefficients and variables in the form of hand movements as if forming the shape of objects that they recognize in the daily environment then followed by consistent and repetitive hand movements as a representation of the coefficients, (3) direct gesture representing constants in the form of hand movements forming a specific number, and (4) writing gestures and pointing gestures to strengthen the explanation given. The present study concludes that the gestures made by the students in understanding the concepts of algebra consist of representation, pointing, and writing. This study yields an important description of students' gestures and types of gestures about the algebraic concept, which provide a further understanding of the topic.
\end{abstract}

Keywords: Gesture, Conceptual understanding, Algebra

\footnotetext{
${ }^{1}$ Mathematics Education Department, Universitas PGRI Semarang, Jl. Sidodadi Timur No. 24 - Dr. Cipto, Semarang 50125, Indonesia, idadwijayanti@upgris.ac.id

2 Postgraduate Mathematics Education, Universitas Negeri Surabaya, Jl. Ketintang Wiyata No. 48, Surabaya 60231, Indonesia
} 


\section{A. Introduction}

Understanding mathematics ideas is an essential goal of learning mathematics (NCTM, 2000; Van de Walle, Karp, \& Bay-Williams, 2010). Students' understanding of mathematical ideas could be identified through either their oral explanation (speech) or body movement or gestures (Shein, 2012). Gestures have become pivotal research topics in education in general and mathematics education in specific since it is considered as evidence where knowledge is embodied (Gibbs, 2006; Hostetter \& Alibali, 2008). In other words, Alibali and Nathan (2011) argue that "gestures are often taken as evidence that the body is involved in thinking and speaking about the ideas expressed in those gestures (p. 248)." Gerofsky (2010) defines gestures as movements of the face, hands, and other parts of the body as a form of non-verbal communication which are employed in a largely unconscious way.

Prior studies (e.g., Nemirovsky \& Ferrara, 2009; Gerofsky, 2010; Alibali \& Nathan, 2011; Shein, 2012) have documented the roles played by gestures in understanding teaching and learning of mathematics. Nemirovsky and Ferrara (2009) found that students made use of the corners of the table in explaining trigonometric concepts through pointing gestures. Gerofsky (2010) studied the use of gestures, movement, and sound when students learn the graphs of polynomial functions. It is concluded that those embodied works could promote students' engagement and understanding. Moreover, Alibali and Nathan (2011) found various gestures produced by students and teachers in explaining mathematical concepts and ideas: representational gestures, metamorphic gestures, and pointing gestures. Shein (2012) showed that a mathematics teacher employs gestures (iconic, representational, and writing) in providing questions to students, revoicing the strategies of students, and recount the meaning of geometric features.

Representational gestures are gestures with hand movements or trajectory movements of the hands or arms representing several objects, actions, concepts, or relationships (Hostetter \& Alibali, 2008; Wu \& Barsalou, 2009; Shein, 2012), For example, a gesture made from a broad angle through the index finger with the position attached to the thumb, then start moving away from the thumb. Pointing gestures is defined as a manifestation of conversation content. The pointing gestures connect between speech and mental processes related to the physical environment (Williams, 2008; Alibali \& Nathan, 2011). For example, a student points to the blackboard when describing rectangular areas. Writing gestures are the integration of hand movements as what the teacher says (Shein, 2012). The metaphorical gestures reflect body-based conceptual representations so that they could be categorized as representational gestures (Alibali \& Nathan, 2011).

The foregoing aforementioned studies and other relevant studies of gestures in the mathematics classroom (e.g., Alibali et al., 2013; Dubé \& McEwen, 2015; Cook et al., 2017) mostly focus on geometry, trigonometry, and arithmetic. The present study focused on a different topic, that is algebra. We argue that each topic in school mathematics has different characteristics; for example, the level of abstractness and involved objects between geometry and algebra. It is possible the students provide other types of gestures when learning different topics such as algebra. Thus, this study further explored students' (possibly different) gestures in understanding the concepts of variables, coefficients, and constant. 


\section{B. Methods}

This study involved 59 seventh-grade students in Semarang city, Indonesia. The students were provided with test 1 to examine their understanding of algebraic concepts, interviewed to explore their results of test 1 and gestures, the recorded interviews were observed thoroughly to determine their gestures, and eventually, the results of test 1, interview, and observation were analysed to draw a conclusion on the students' tendency in understanding algebraic concepts using gestures or not. One student who represents the group of students who used gestures and scored 91-100 on the test was purposively chosen as subject to be further studied. The subject followed the same procedures: given test 2 , second interview, observation of recorded interview, and the analysis of three prior sources of data. Test 1 and test 2 used similar problems (Table 2), but they were given at different times.

Data on the subject's gesture was analysed in three stages: data condensation, data display, and drawing and verifying conclusion (Miles, Huberman, \& Saldana, 2014). At the stage of data condensation, we grouped the subject's gestures based on the indicators of conceptual understanding. Unrelated gestures were ignored; for example, the students scratched his head or cancelled explanations. After the data was grouped, it was presented in the form of narrative dialogue. At the last stage, the results of the subjects' gestures in the first and second interviews were then compared to see whether their gestures are consistent when explaining each concept (variables, coefficients and constants). If the results were the same, then the conclusion was drawn. For example, in the first interview, the subject stated $2 x+5$ as 2 boxes and 5 books (his hand formed a box, the number 2 and 5 was represented in " $v$ " form of hand movement, and he spanned his five fingers). In the second interview, he represented $2 x+5$ as 2 candy boxes and 5 candies (his hand moved as if holding a bottle then turned left and right, 2 and 5 was represented in " $v$ " form of hand movement, and his fingers were spanned). The data was said to be consistent since he had similar direct gestures in representing a variable, coefficient, and constant.

We carefully developed the test instrument, interview guideline, and observation sheet to respectively examine students' conceptual understanding of algebra and students' gestures (Dwijayanti, Budayasa, \& Siswono, 2018). In this case, the test instrument has been validated in terms of validity and reliability. Item validity is the understanding of test items, which was analyzed using the product-moment correlation formula. An instrument is said to be valid if the $r_{x y}$ coefficient (count) obtained is higher than $r$ Table at a significance level of 5\%. The results are presented in Table 1. It shows that the results of the overall examination are declared valid, which mean that the test can measure the students' understanding of algebraic form (Azwar, 2014; Golafshani, 2003). A reliability test was performed using the KR-21 formula, which results in 0.6118 , a high-reliability score. This means that the test will generate consistent results (Azwar, 2014).

Table 1. The validation results of test items

\begin{tabular}{lccccccc}
\hline Item & $\mathbf{1}$ & $\mathbf{2}$ & $\mathbf{3}$ & $\mathbf{4}$ & $\mathbf{5}$ & $\mathbf{6}$ & $\mathbf{7}$ \\
\hline & 0,66 & 0,70 & 0,54 & 0,58 & 0,40 & 0,37 & 0,66 \\
$\mathrm{r}_{\text {Table }}$ & 0,35 & 0,35 & 0,35 & 0,35 & 0,35 & 0,35 & 0,35 \\
Criteria & Valid & Valid & Valid & Valid & Valid & Valid & Valid \\
\hline
\end{tabular}

The interview guideline and observation sheet has been validated in terms of construct, content, and face. The construct and content validity was done through expert judgment and 
declared as valid. As for face validity, a readability test by students was applied. The results show that the instrument has good readability. Table 2 shows the excerpts of the developed instruments. The indicators of conceptual understanding were: interpreting, exemplifying, classifying, summarizing, inferring, comparing, and/or explaining (Anderson \& Krathwohl, 2001).

\section{Findings and Discussion}

Table 3 shows students' scores in test 1 . It is less than $20 \%$ of students who fulfilled the indicators of understanding.

Table 3. The results of test 1

\begin{tabular}{lc}
\hline Scores & Number of students \\
\hline$<61$ & 8 \\
$61-70$ & 11 \\
$71-80$ & 11 \\
$81-90$ & 17 \\
$91-100$ & 12 \\
\hline
\end{tabular}

The observations on 59 students' interview resulted in two tendencies when understanding algebraic expressions. Forty-nine students tended to show their understanding in the form of gestures (group 1), and the remaining students used intonation and facial expressions (Group 2). For example, some students in group 1 interpreted $2 x+5$ by turning into $2 x$ (directed the view to the right), mentioning 'can' (directed the gaze to the researchers then forming movements with the right hand on his stomach then turned $180^{\circ}$ ), 2 cans (while forming a symbol of 2 using the right hand) and 5 (directed the view to the right for a few moments then directed the view back to the researcher accompanied by the movement of the right hand forming a symbol of 5) candies (while making writing movements in the air). Several students in group 2 turned $2 x+3 y$ into two egg boxes (answered smoothly, then moved the eyeball up) plus three egg cans. They did not use body movements as a form of understanding the concepts they have but employed the intonation of sound and eyeball movements as a representation.

To identify the students' gestures deeper, one student who represented group 1 and scored 91-100 in test 1 was purposively selected and given test 2 then interviewed. We found the student's gestures emerged in each indicator are as follows. In interpreting, he had direct gesture to represent variables, coefficients, and constant and writing gesture. In exemplifying, he created an indirect gesture to represent variable and coefficient. In classifying and inferring, he provided a pointing gesture. In summarizing, he had direct gesture which represents the number 1, 2 and 3 when identifying the elements of algebraic expressions. In comparing, he used writing gesture. And in explaining, he showed writing and pointing gesture. Similar gestures emerged in different indicator of understanding. Indeed, we only focussed on describing the direct and indirect representational gestures, writing gestures, and pointing gestures when the student interpreted, exemplified, and explained algebraic expression. 
Table 2. The excerpts of the test instrument, interviewing questions and observation sheet

\begin{tabular}{|c|c|c|c|}
\hline $\begin{array}{l}\text { Indicators of } \\
\text { understanding }\end{array}$ & Problems & Interviewing questions & $\begin{array}{l}\text { Observation } \\
\text { guideline }\end{array}$ \\
\hline Interpreting & $\begin{array}{l}\text { 1. Change the following sentence into mathematical } \\
\text { expression! } \\
\text { a. I have } 2 \text { cans of candy and } 5 \text { candies } \\
\text { b. Silvi packs books into } 2 \text { large boxes and } 3 \text { small } \\
\text { boxes }\end{array}$ & $\begin{array}{l}\text { a. Can you make a mathematical expression from } \\
\text { that sentence? } \\
\text { b. Explain the mathematical expression you wrote } \\
\text { down. }\end{array}$ & $\begin{array}{l}\text { a. Doing the writing } \\
\text { movement of the } \\
\text { given problem } \\
\text { b. Doing hand } \\
\text { movements in a }\end{array}$ \\
\hline Exemplifying & $\begin{array}{l}\text { 2. Consider the following expressions! } \\
\begin{array}{ll}\text { a. } 3 a+1 & \text { d. } 2 y+4=8 \\
\text { b. } 3+7 & \text { e. } a^{2}-b+5 \\
\text { c. }(x+2)(y-5) & \text { f. } x+2 y+2 \\
\text { They are examples and not examples of algebraic } \\
\text { expression. Make five examples of algebraic } \\
\text { expressions! }\end{array}\end{array}$ & $\begin{array}{l}\text { a. Explain the algebraic expression you are writing } \\
\text { about! } \\
\text { b. Can you change expression in (a) into a real } \\
\text { situation like the number } 1 \text { ? }\end{array}$ & $\begin{array}{l}\text { circle and boxes as } \\
\text { the representation } \\
\text { of cans } \\
\text { c. Making pointing } \\
\text { gestures on the text } \\
\text { or certain object as } \\
\text { reinforcement. }\end{array}$ \\
\hline Classifying & $\begin{array}{l}\text { 3. Are the following expressions algebraic or not? Give } \\
\text { your reason! } \\
\text { a. } 3 \mathrm{p}+2 \\
\text { b. } 5 \mathrm{a}^{2}-\mathrm{b}+\mathrm{ab} \\
\text { c. } 4 \mathrm{p}^{3}+2 \mathrm{p}^{2} \mathrm{t}-3 \mathrm{pt}^{2}-\mathrm{t}^{3}+9 \\
\text { d. } 2 \mathrm{a}+4=8 \\
\text { e. } 3+7 \\
\text { f. }(\mathrm{x}+\mathrm{y})^{2}=\mathrm{x}^{2}+2 \mathrm{xy}+\mathrm{y}^{2}\end{array}$ & $\begin{array}{l}\text { a. Can you change the expression into daily context? } \\
\text { b. Are they algebraic expressions? Why? }\end{array}$ & \\
\hline Summarizing & $\begin{array}{l}\text { 4. Based on the answers of no. 3, mention the } \\
\text { characteristics of the algebraic expressions! }\end{array}$ & $\begin{array}{l}\text { Are there any characteristics other than what you } \\
\text { mentioned? }\end{array}$ & \\
\hline Inferring & $\begin{array}{l}5 . \text { Based on the characteristics of the algebraic expressions, } \\
\text { write its definition! }\end{array}$ & $\begin{array}{l}\text { What do you think about the definition of algebraic } \\
\text { expressions? }\end{array}$ & \\
\hline Comparing & $\begin{array}{l}\text { 6. What are the differences between algebraic expressions } \\
\text { and non- algebraic expressions? }\end{array}$ & Similar to the problem no. 6 & \\
\hline Explaining & $\begin{array}{l}\text { 7. Given the expression: } x^{2}+x y+4 x+5 y-5 \text {. } \\
\text { a. If it is changed to }(x+5)(x+y-1) \text {, is it still an } \\
\text { algebraic expression? Why? } \\
\text { b. If it is changed to } x^{2}+x y+4 x+5 y=5 \text {, is it still an } \\
\text { algebraic expression? Why? }\end{array}$ & Similar to the problem no. 7 & \\
\hline
\end{tabular}


Data about gestures obtained through interviews are presented by giving a three-digit code consisting of 1 letter and two numbers. The letter $\mathrm{R}$ and $\mathrm{S}$ respectively represent the researchers and students, while the numeric code on digit 2 represents the question number.

\section{Interpreting}

The student performed indirect representational gestures of variables and coefficients in the interpreting process. The following is the excerpt of the interview.

\begin{tabular}{|c|c|}
\hline$R 01$ & $\begin{array}{l}\text { The statement "Silvi packs the books in } 2 \text { large boxes and three } \\
\text { small boxes," what is the mathematical expression of this } \\
\text { statement? }\end{array}$ \\
\hline S01 & $: 2 x+3 y$ \\
\hline$R 02$ & : Can you explain it? \\
\hline SO2 & $\begin{array}{l}2 x \text { is the number of unknown books in large boxes (at the same } \\
\text { time making the right-hand stretch and as if holding a large size } \\
\text { twice shown in Figure 1) and } 3 y \text { is the number of unknown books } \\
\text { in small boxes (at the same time making a movement to unite all the } \\
\text { fingers of the right hand then move towards three different points } \\
\text { as shown in Figure 2) }\end{array}$ \\
\hline
\end{tabular}

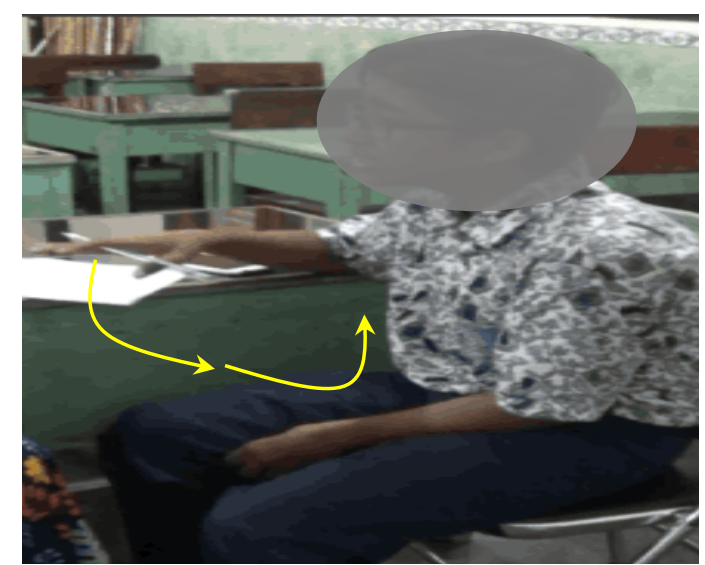

Figure 1. Indirect representational gestures of variable and coefficient

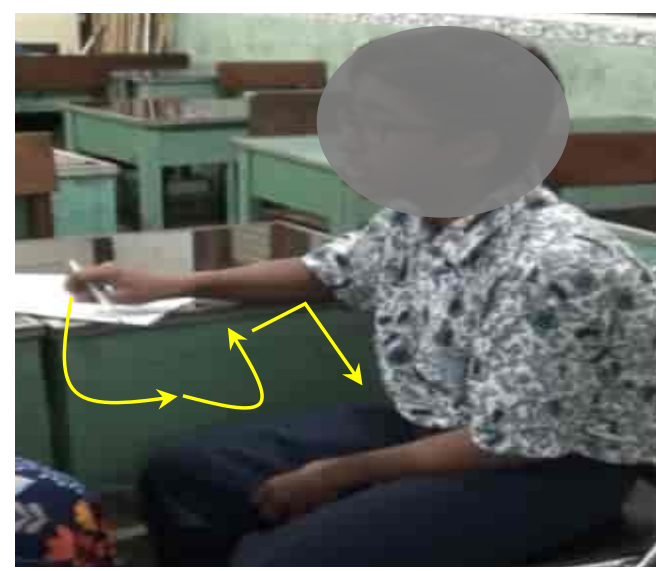

Figure 2. Indirect representational gestures of variable and coefficient

Figure 1 shows that the student performed indirect representations of variables: In this case, the books, whose number was unknown, placed in a large box, through the position of the fingers stretched as if representing a large box and an indirect representation of the coefficients through progressive hand movements in two different directions. On the other hand, Figure 2 shows that the student performed indirect representations of variables, in this case, the books, whose number was unknown placed in a small box, through the position of the fingers gathered together as if representing a small box and an indirect representation of the coefficients through continuous hand movements in three different directions. 


\section{Exemplifying}

The student performed direct representational gestures of coefficients, variables, and constants in the exemplifying process. The excerpt of the interview is presented below.

\begin{tabular}{|c|c|}
\hline$R 03$ & $\begin{array}{l}\text { Observe which expressions are algebraic and non-algebraic } \\
\text { (shows a piece of paper that contains some text, as shown in } \\
\text { Figure 3)! Can you give another example of an algebraic } \\
\text { expression? }\end{array}$ \\
\hline S03 & $\therefore 2 x-9$ \\
\hline$R 04$ & : How do you come up with the example? What's in your mind? \\
\hline S04 & $\begin{array}{l}\text { Pak Yosan has two (at the same time forming symbol } 2 \text { using the } \\
\text { right hand as shown in Figure 4) packs (at the same time, making } \\
\text { hand movements form a box, as shown in Figure 5) of books. Then } \\
\text { Mr Yosan gave nine books to his son (at the same time, the } \\
\text { movement folds the entire radius and leaves one finger standing, } \\
\text { as shown in Figure 6). }\end{array}$ \\
\hline
\end{tabular}
a. $3 a+1$
b. $x+2 y+2$
c. $3+7$
d. $4 \mathrm{x}$
e. 2
f. $2 y+4=8$
g. $a^{2}-b+5$
h. $u v+u-v$
i. $2 x^{2}+3 y-z+3$
j. $(x+y)^{2}=x^{2}+2 x y+y^{2}$
k. $(\mathrm{x}+2)(\mathrm{y}-5)$
1. $(a-3)(b+2)=6$

Figure 3. A set of algebraic expressions

Figure 4 shows that the student used a direct representation of the coefficients through hand movements forming " $\mathrm{v}$ " as a symbol of number 2. In Figure 5, the student employed a direct representation of a variable, in this case, the number of books that are not yet known in a box, through the movements of the hands forming a box. Figure 6 shows student's use of direct gesture, which represent the constants through movement that folds the entire radius and leaves one finger standing.

\section{Explaining}

The student performed writing gestures and pointing gestures in the explaining process. The excerpt of the interview is as follows. 
R05 : You have noticed $x^{2}+x y+4 x+5 y-5$. If $5 a$ is added, is it still an algebraic expression?

S05 : (writing on paper, as shown in Figure 8) Yes.

R07 : Even though the variables are different?

S07 : Yes

R08 : Why?

S08 : Because it has variables, coefficients, constants (at the same time making a pointing gesture on paper as shown in Figure 7)

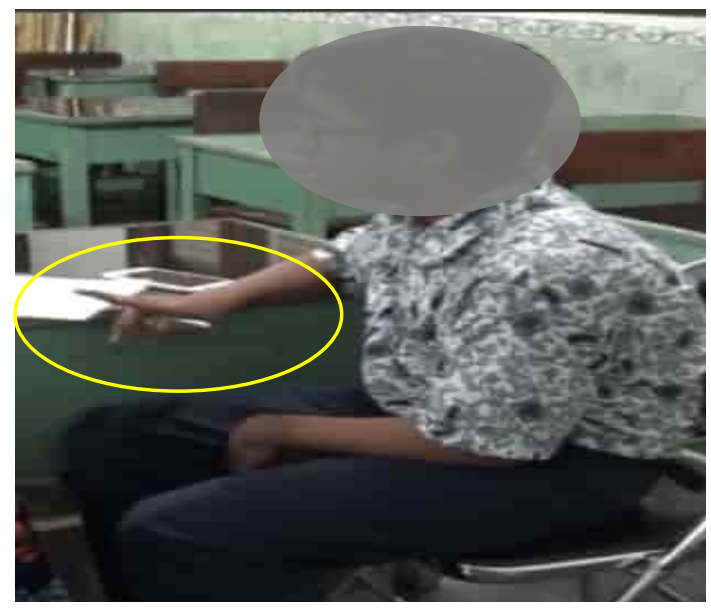

Figure 4. Representational gestures of the coefficient

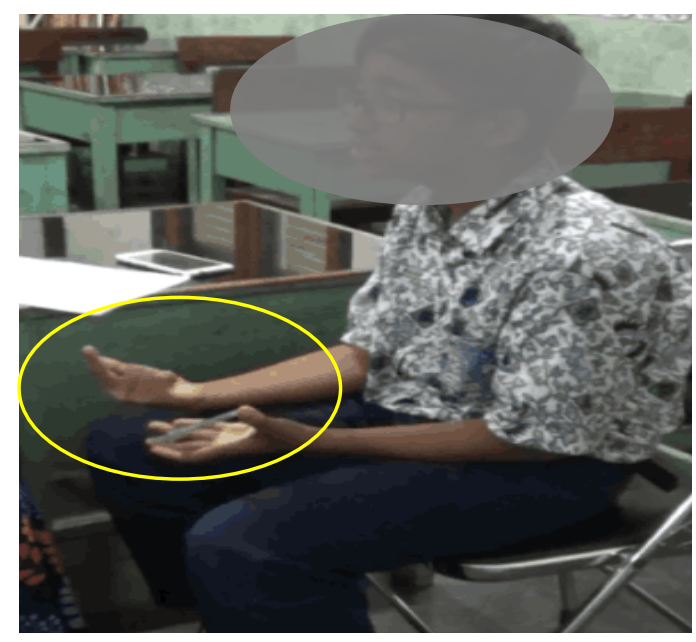

Figure 6. Representational gestures of constants

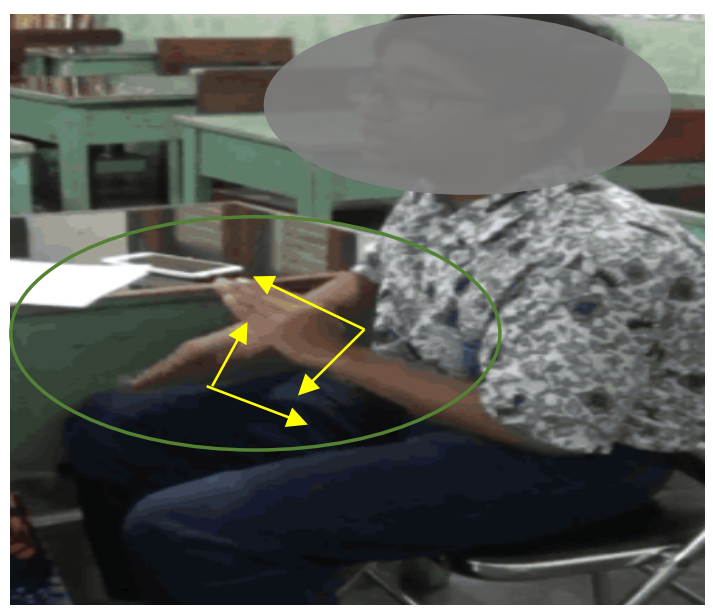

Figure 5. Representational gestures of variable

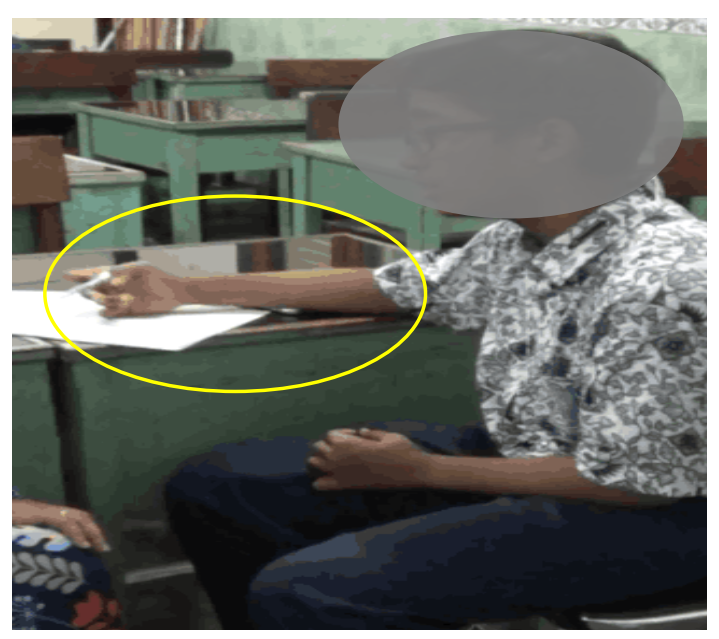

Figure 7. The student used pointing gestures

In Figure 7, the student used gestures as an attempt to reinforce explanations about variables, coefficients, and constants by pointing to $5 \mathrm{a}+\mathrm{x}^{2}+\mathrm{xy}+4 \mathrm{x}+5 \mathrm{y}-5$ on the paper as a symbol of the variables, coefficients, and constants. 


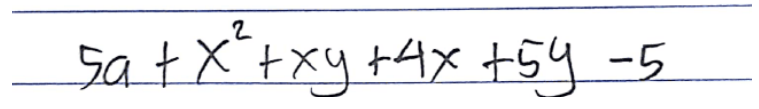

Figure 8. The student's writing gesture

The prior study on gestures (Alibali \& Nathan, 2011) explained that gestures could be utilized during the learning process in the form of representational, writing, and pointing gestures. More specifically, it described gestures created by the students in understanding the slope of line equations by doing movements, as shown in Figure 9. Besides, the students also employed writing and pointing gestures to affirm the explanations given, as shown in Figure 10. If we compare it with the current study, there is evidence of gesture consistency created by the students in understanding mathematical concepts.

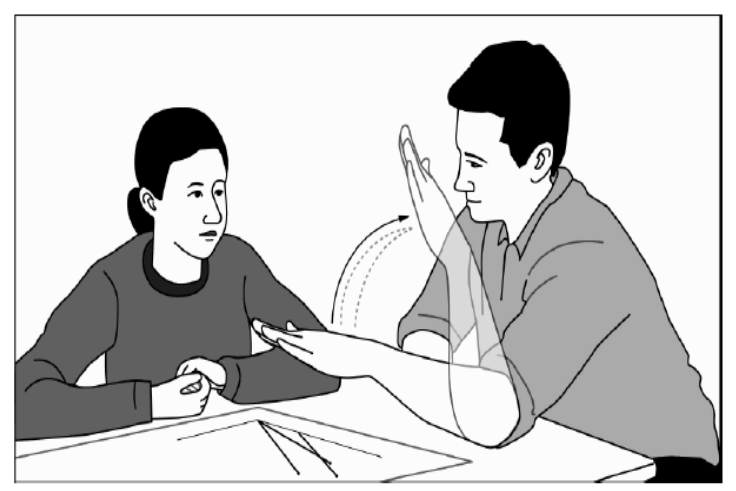

Figure 9. Representational gestures of a slope of the line (Alibali \& Nathan, 2011, p.15)

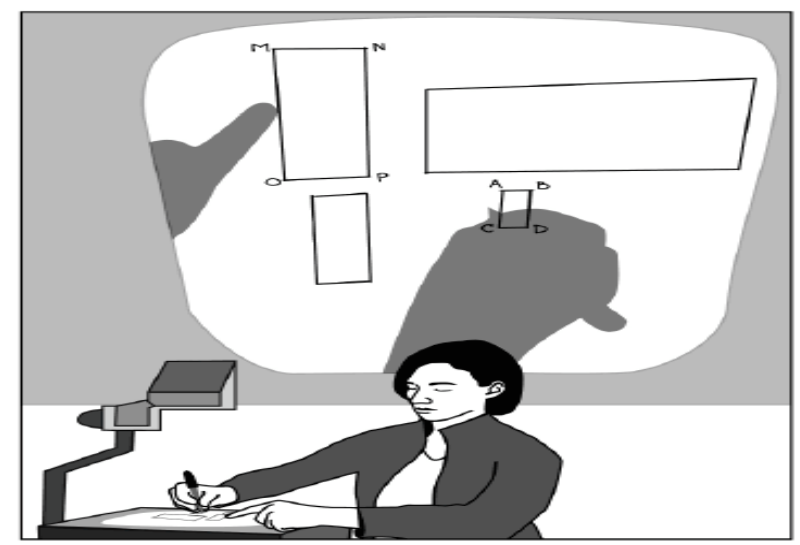

Figure 10. Writing and pointing gestures (Alibali \& Nathan., 2011, p.12)

The contribution of this present study is the description of the students' gestures about the algebraic concept, whereas prior studies (e.g., Alibali et al., 2013) focused on geometry topics such as graphs. Moreover, we found two types of representational gestures: direct and indirect. The direct representational gesture was used by the students when describing $2 x-9$ (Figure 4, Figure 6, Figure 7). The indirect representational gesture was utilized by the student when explaining $2 x+3 y$. The students performed indirect representations of variables (Figure 
1, Figure 2, Figure 5). These gesture's names refer to the definition of the representational gestures: A movement describing semantic content, either literally or figuratively, through handshape or trajectory (Hostetter \& Alibali, 2008). The indirect representational gestures gave an example of the representational gestures through metaphors mentioned in the prior report (Alibali \& Nathan, 2011).

The experience of interacting with an empty box was used by the student to understand the concept of variables through representation. In addition, with designated gestures, the student employed visible $5 \mathrm{a}+\mathrm{x} 2+\mathrm{xy}+4 \mathrm{x}+5 \mathrm{y}-5$ to manifest the coefficients, variables, and constants in her mind. This shows that motor-sensory experience (what is seen, heard, and felt) influences conceptual representation (Glenberg \& Gallese, 2012). What the student did in interpreting follows the theory, which states that sensorimotor interactions help the primary concepts during the acquisition of initial knowledge (Laakso, 2011). Representations are abstracted from initial experience and then organized to form conceptual knowledge (Gennari, 2012; Meteyard et al., 2012; Foglia \& Wilson, 2013). Furthermore, the results of the current study support prior studies on how gestures are derived from experiences owned by children, which contribute as a cognitive foundation in the process of conceptual development (Borghi \& Cimatti, 2010; Gabbard, 2013).

\section{Conclusion}

This study found that students' gestures in understanding algebraic concepts consisted of representation, pointing, and writing. Direct gestures as a representation of coefficients and variables in the form of hand movements forming the shape of objects that they recognize in the everyday environment. Indirect gestures as a representation of coefficients and variables in the form of hand movements as if forming the shape of objects that they recognize in the daily environment then followed by consistent and repetitive hand movements as a representation of the coefficients. The representational gesture of constants in the form of hand movements forming an individual number. Writing gestures and pointing gestures to strengthen the explanation given. The use of different mathematics topics (algebra) in this study results in an indirect gesture which had not been identified in geometry topics. The mathematics topics with unique characteristics might create distinct types of gestures used by students.

\section{Acknowledgments}

We are grateful to Ms Roca, a seventh-grade mathematics teacher, for her support during the study and $7^{\text {th }}$-grade students (Class VIID and VIIG) SMP Negeri 2 Semarang for their cooperation.

\section{References}

Alibali, M. W., \& Nathan, M. J. (2011). Embodiment in mathematics teaching and learning: Evidence from learners' and teachers' gestures. [Special Issue on Embodiment in Mathematics]. Journal of The Learning Sciences, 21(2), 247-286. Doi: 10.1080/10508406.2011.611446 
Alibali, M. W., Young, A. G., Crooks, N. M., Yeo, A., Wolfgram, M. S., Ledesma, I. M., ... \& Knuth, E. J. (2013). Students learn more when their teacher has learned to gesture effectively. Gesture, 13(2), 210-233. Doi: 10.1075/gest.13.2.05ali

Anderson, L. W., \& Krathwohl, D. R. (2001). A taxonomy for learning, teaching and assessing: a revision of Bloom's taxonomy. New York: Longman Publishing.

Azwar, S. (2014). Psikologi inteligensi. Yogyakarta: Pustaka Pelajar.

Borghi, A. M., \& Cimatti F. (2010). Embodied cognition and beyond: Acting and sensing the body. Neuropsychologia, 48(3), 763-73. Doi: 10.1016/j.neuropsychologia.2009.10.029

Dubé, A. K., \& McEwen, R. N. (2015). Do gestures matter? The implications of using touchscreen devices in mathematics instruction. Learning and Instruction, 40, 89-98. Doi: 10.1016/j.learninstruc.2015.09.002

Dwijayanti, I., Budayasa, I.K., \& Siswono, T.Y.E. (2018). Student mathematical imagination instruments: Construction, cultural adaptation and validity. Journal of Physics: Conf. Series, 983 (012132): $1-6$.

Cook, S. W., Friedman, H. S., Duggan, K. A., Cui, J., \& Popescu, V. (2017). Hand gesture and mathematics learning: Lessons from an Avatar. Cognitive Science, 41(2), 518-535. Doi: $10.1111 / \operatorname{cogs} .12344$

Foglia, L., \& Wilson, R. A. (2013). Embodied cognition. WIREs Cognitive Science, 4(3), 319-325.

Gabbard C. (2013). The role of mental simulation in embodied cognition. Early Child Dev. Care, 183, 643-650. Doi: 10.1080/03004430.2012.681649

Gennari S. P. (2012). Representing motion in language comprehension: Lessons from neuroimaging. Language and Linguistics Compass, 6(2), 67-84. Doi: 10.1002/lnc3.317

Gerofsky, S. (2010). Mathematical learning and gesture: Character viewpoint and observer viewpoint in students' graphs of functions. Gesture, 10(2-3), 321-343. Doi: 10.1075/gest.10.2-3.10ger

Gibbs, R. W. (2006). Embodiment and cognitive science. Cambridge, England: Cambridge University Press.

Glenberg, A. M., \& Gallese, V. (2012). Action-based language: a theory of language acquisition, comprehension, and production. Cortex, 48(7), 905-922. Doi: 10.1016/j.cortex.2011.04.010

Golafshani, N. (2003). Understanding reability and validity in qualitative research. The Qualitative Report. 8(4), 597-607.

Hostetter, A. B., \& Alibali, M. W. (2008). Visible embodiment: Gestures as simulated action. Psychonomic Bulletin \& Review, 15(3), 495-514. Doi: 10.3758/pbr.15.3.495

Laakso A. (2011). Embodiment and development in cognitive science. Cogn. Brain Behav, 15(4), 409-425.

Meteyard, L., Cuadrado, S. R., Bahrami, B., \& Viglicco, G. (2012). Coming of age: A review of embodiment and the neuroscience of semantics. Cortex, 48(7), 788-804. Doi: 10.1016/j.cortex.2010.11.002

Miles, M. B., Huberman, A. M., dan Saldana, J. (2014). Qualitative Data Analysis, A Methods Sourcebook, Edition 3. USA: Sage Publications.

NCTM. (2000). Principles and standards for school mathematics. Reston, VA: NCTM.

Nemirovsky, R., \& Ferrara, F. (2009). Mathematical imagination and embodied cognition. Educational Studies in Mathematics, 70(2), 159-174. Doi: 10.1007/s10649-008-9150-4

Shein, P. P. (2012). Seeing with two eyes: A teacher's use of gestures in questioning and revoicing to engage English language learners in the repair of mathematical errors. Journal for Research in Mathematics Education, 43(2), 182-222. Doi: 10.5951/jresematheduc.43.2.0182

van de Walle, J.A., Karp, K.S., \& Bay-Williams, J.M. (2010). Elementary and middle school mathematics: Teaching developmentally (7th edition). Allyn \& Bacon: Boston.

Williams, R. F. (2008). Gesture as a conceptual mapping tool. In A. Cienki \& C. Müller (Eds.), Metaphor and Gesture. Amsterdam, The Netherlands: John Benjamins.

Wu, L. L., \& Barsalou, L.W. (2009). Perceptual simulation in conceptual combination: Evidence from property generation. Acta Psychologica, 132(2), 173-189. Doi: 10.1016/j.actpsy.2009.02.002 